\title{
Effectiveness of Lactate Dehydrogenase to Albumin Ratio in the Diagnosis of Pulmonary Thromboembolism
}

\section{Laktat Dehidrojenaz Albumin Oranının Pulmoner Emboli Tanısında Etkinliği}

\author{
Recep Alanlı®, Murat Bülent Küçükay ${ }^{\circledR}$, Kadir Serkan Yalçın®
}

Lokman Hekim University, Faculty of Medicine, Department of Internal Medicine, Ankara, Turkey

Received: 22.07.2020 / Accepted: 05.01.2021 / Published Online: 31.03.2021

Cite as: Alanlı R, Küçükay MB, Yalçın KS. Effectiveness of lactate dehydrogenase to albumin ratio in the diagnosis of pulmonary thromboembolism. Med J Bakirkoy 2021;17(1):25-9.

\begin{abstract}
Objective: The aim of the study is to inspect effectiveness of lactate dehydrogenase (LDH) to albumin ratio (LAR) in patients with pulmonary thromboembolism (PTE).

Method: A total of 307 patients who admitted to emergency unit, between January 2017 and March 2020, with chest pain and sudden onset of dyspnea were enrolled in this single-center and retrospective study. Computed tomography pulmonary angiogram (CTPA) was performed to confirm pulmonary embolism.

Results: LAR, neutrophil, monocyte, D-dimer, LDH values were significantly higher and albumin values were significantly lower in patients with pulmonary embolism compared to those without. Average age of 307 participants were 68.93 years. While 140 patients had confirmed PTE and 167 were without PTE. Linear regression analysis for LAR in the diagnosis of PTE, revealed a correlation coefficient as $r=0.320$ ( $p<0.001)$. Positive and negative predictive values for LAR in the diagnosisi of PTE were, $63.3 \%$ and $75.2 \%$, respectively. In ROC analysis relation of LAR to PTE was found to be stronger than $L D H$ and albumin alone.

Conclusion: LAR, which is a very simple and available test, may be used as a novel parameter in the diagnosis of PTE.
\end{abstract}

Keywords: albumin, lactate dehydrogenase, lactate dehydrogenase to albumin ratio, pulmonary thromboembolism

öz

Amaç: Bu çalışmanın amacı laktat dehidrojenaz albumin oranının (LAR) pulmoner tromboemboli (PTE) tanısındaki etkinliğini incelemektir. Yöntem: Bu tek merkezli, retrospektif çalışmada, Ocak 2017 ile Mart 2020 tarihleri arasında acil servise göğüs ağrısı ve ani gelişen dispne nedeniyle başvuran ve PTE şüphesi ile PBTA yapılmış olan 307 hasta incelendi.

Bulgular: PTE saptanan hastalarda, PTE saptanmayan hastalarla kıyaslandığında; LAR, nötrofil ve monosit sayımları, d-dimer ve LDH değerleri anlamlı olarak yüksek bulunurken, albumin değerleri anlamlı olarak daha düşük bulundu. Katılımcıların ortalama yaşı 68,93 olarak bulundu; 140 hastada PTE saptanırken 167'sinde PTE saptanmadı. LAR ile PTE arasındaki lineer regresyon analizinde korrelasyon katsayıSI $r=0,320$. LAR için pozitif prediktif değer $\% 63,3$, negatif prediktif değer $\% 75,2$ olarak bulundu. Receiver operator characteristics (ROC) eğrisi incelemesinde LAR ile PTE arasındaki ilişki, tek başına LDH veya albumin testlerinden daha güçlü bulunmuştur. Sonuç: Basit ve her yerde yapılabilir bir test olarak LAR, PTE tanısında yeni bir parametre olarak kullanılabilir.

Anahtar kelimeler: albumin, laktat dehidrojenaz, laktat dehidrojenaz albumin oranı, pulmoner tromboembolizm

Corresponding Author:

$\checkmark$ recepalanli@gmail.com
R. Alanlı 0000-0003-4663-1898 M.B. Küçükay 0000-0003-3657-6565 K.S. Yalçın 0000-0002-8028-1070

(C) Telif hakkı Sağlık Bilimleri Üniversitesi Bakırköy Dr. Sadi Konuk Eğitim ve Araştırma Hastanesi'ne aittir. Logos Tıp Yayıncılık tarafindan yayınlanmaktadır. Bu dergide yayınlanan bütün makaleler Creative Commons Atff-GayriTicari 4.0 Uluslararası Lisansı ile lisanslanmıştı. 


\section{INTRODUCTION}

Pulmonary thromboembolism (PTE) presents with sudden chest pain and shortness of breath usually caused by an underlying aggravating condition and obstruction of pulmonary arterial blood flow due to thrombus, tumor, fat or air ${ }^{(1)}$. It is the third most common reason of death in hospitalized patients ${ }^{(2)}$.

After onset of PTE, inflammatory cells accumulate in arterial walls and in a few hours, inflammation exaggerates and peaks in two days (3). Lactate dehydrogenase (LDH) and albumin levels are basic and inexpensive tests reflecting inflammation. Albumin is a negative acute phase reactant, and its levels decrease in inflammatory conditions. Hypoalbuminemia will result in loss of antithrombotic proteins through renal glomeruli which will increase the risk of venous thromboembolism ${ }^{(4)}$. A study with general population revealed that hypoalbuminemia causes an increase in the risk of venous thromboembolism (5). Hypoxic and ischemic conditions will cause cellular injury and trigger an increase in $\mathrm{LDH}{ }^{(6)}$.

Although both LDH and albumin are known inflammatory markers, there are few studies about ratio of $L D H$ to albumin (LAR) as an inflammatory marker. LAR previously was reported as a prognostic indicator of survival in patients having esophagus, hepatocellular and pancreas cancers ${ }^{(7-9)}$. Also, in patients in intensive care unit, LAR was associated with multiple organ failures and 30-day mortality rates ${ }^{(10)}$. LAR in diagnosis and predicting prognosis of PTE has not been previously evaluated.

Computed tomography pulmonary angiogram (CTPA) is an effective diagnostic procedure in diagnosis of PTE, but it may be performed in major health institutes and requires radiology specialist for evaluation. High cost of procedure, necessity of patient cooperation are disadvantages and also patient must have normal renal functions before procedure. Cheap, simple and practical tests are still required for the diagnosis of PTE. Therefore, LAR may be a novel and simple marker in PTE. In this study, we aimed to investigate the effectiveness of LAR in the diagnosis of PTE.

\section{METHOD}

This study was conducted retrospectively as single center in a university hospital. Between January 2017 and March 2020, 307 patients who admitted to emergency unit with chest pain and sudden onset of dyspnea complaints and in whom CTPA were performed with the suspicion of pulmonary embolism were enrolled in the study. A hundred and forty patients (46\%) in whom CTPA revealed thromboembolism were enrolled in the study group and 167 (54\%) patients in whom CTPA reported to be normal were accepted as the control group. Patients below 18 years of age and patients whose laboratory test results could not be obtained completely were excluded. This study was approved by the local ethics committee (Approval no: 2020014). Informed written consent was obtained from all of the patients participated in the study.

Demographic information, laboratory findings, echocardiography and CTPA images of patients were retrieved from hospital data processing and information services. Whole blood counts (neutrophil, lymphocyte, monocyte counts), mean corpuscular volume (MCV), mean platelet volume (MPV), red cell diameter width (RDW), LDH, D-dimer, albumin and uric acid levels were recorded.

Whole blood count tests were analyzed in Sysmex XN-1000 (USA) hematology analyzer. Albumin, LDH, $\mathrm{d}$-dimer and uric acid tests were analyzed in Roche Hitachi Cobas 501 (Switzerland) analyzer. Thorax tomography was performed by Siemens Emotion 16 Scanner (Siemens Healthineers; Erlangen, Germany, 2010) using the following parameters: $110 \mathrm{kV}, 258$ $\mathrm{mA}$, slice thickness of $1,5 \mathrm{~mm}$. All scans were performed without intravenous contrast with the patient in the supine position during end-inspiration. Tomography images were evaluated by a 15 years experienced radiologist. Echocardiographies were examined by a 17 years experienced radiologist and pulmonary artery pressures (PAP) were noted.

CTPA was performed in patients who had complaints of dyspnea and chest pain and patients who had thrombus in pulmonary arterial system were diagnosed as PTE. 
SPSS for Windows 25.0 statistical software package (SPSS Inc., Chicago, IL, USA) was used for statistical analysis of the data. All parameters were given as the mean \pm standard deviation and $p$ value $<0.05$ was considered statistically significant. Data distribution were evaluated by Shapiro-Wilk test. Comparison between groups were evaluated by independent t-test and Mann-Whitney $U$ test if t-test was not applicable. In the receiver operator characteristics curve (ROC), the area under the curve (AUC) was used to determine diagnostic cut-off values for LDH/ albumin ratio in predicting pulmonary thromboembolism.

\section{RESULTS}

Neutrophil, monocyte, D-dimer, LDH values were significantly higher and albumin values were significantly lower in patients with pulmonary embolism compared to those without. LDH/albumin ratio was higher in patients with pulmonary embolism. Pulmonary artery pressures in echocardiographies were higher in pulmonary embolism group. Demographic information and laboratory values of patients enrolled in study are shown in Table 1.
A total of 307 patients were enrolled in the study including 119 (\%38.8) male and 188 (\%61.2) female participants. Mean age of the participants were $68.93 \pm 14.31$ years. Mean ages of the male, and female participants were $67.77 \pm 14.45$, and $69.67 \pm 14.21$ years, respectively.

In order to determine the effectiveness of LDH, albumin and $\mathrm{LDH} /$ albumin ratios to predict pulmonary embolism, ROC curve analysis was done and LDH/albumin ratio was found to be the best effective test. ROC curve analysis is shown in Figure 1. Area under the curve (AUC) values for $\mathrm{LDH} /$ albumin, $\mathrm{LDH}$ and albumin are shown in Table 2. Optimal cut-off value for LDH/albumin ratio was 78.93 (72\% sensitivity, 68\% specificity), as shown in Figure 1. Linear regression analysis for LAR in the diagnosis of PTE, revealed a correlation coefficient as $r=0.320(p<0.001)$. Sensitivity, specificity, positive and negative predictive values for LAR in the diagnosis of pulmonary thromboembolism are shown in Table 3.

Table 2: Area under the curve values for LDH/albumin, LDH and albumin.

\begin{tabular}{|l|c|c|}
\hline Parameters & Area under the curve & p value \\
\hline $\mathrm{LDH}^{*} /$ albumin & $0.727(0,665-0,790)$ & $<0.001$ \\
\hline $\mathrm{LDH}$ & $0.713(0.648-0.777)$ & $<0.001$ \\
\hline Albumin & $0.355(0.288-0.423)$ & $<0.001$ \\
\hline
\end{tabular}

${ }^{*}$ Lactate dehydrogenase

Table 1: Demographic information and laboratory values of patients enrolled in the study.

\begin{tabular}{|c|c|c|c|}
\hline & $\begin{array}{l}\text { Pulmonary embolism (+) } \\
\qquad(\mathrm{n}=140)\end{array}$ & Pulmonary embolism (-) ( $n=167)$ & $p$ value \\
\hline Age (years) & $68.89 \pm 13.91$ & $69.97 \pm 14.68$ & 0.963 \\
\hline Male/female & $55 / 85$ & $64 / 103$ & 0.864 \\
\hline Neutrophil $\left(\times 10^{6} / \mathrm{L}\right)$ & $8.11 \pm 3.99$ & $6.32 \pm 3.22$ & $<0.001$ \\
\hline Lymphocyte $\left(\times 10^{6} / \mathrm{L}\right)$ & $2.27 \pm 1.57$ & $1.96 \pm 1.43$ & 0.078 \\
\hline Monocyte $\left(\times 10^{6} / \mathrm{L}\right)$ & $0.97 \pm 0.45$ & $0.59 \pm 0.21$ & $<0.001$ \\
\hline $\mathrm{MCV}^{*}(\mathrm{fL})$ & $84.24 \pm 5.70$ & $83.97 \pm 7.32$ & 0.730 \\
\hline $\mathrm{MPV}^{+}(\mathrm{fL})$ & $10.14 \pm 1.02$ & $10.21 \pm 1.08$ & 0.582 \\
\hline $\mathrm{RDW}^{\ddagger}(\%)$ & $14.56 \pm 2.37$ & $14.87 \pm 2.51$ & 0.279 \\
\hline D-dimer (nmol/L) & $5008 \pm 2822$ & $2679 \pm 2619$ & $<0.001$ \\
\hline Lactate dehydrogenase (U/L) & $307.36 \pm 125$ & $258.18 \pm 105$ & 0.001 \\
\hline Albumin (g/dl) & $3.20 \pm 0.66$ & $3.55 \pm 0.63$ & $<0.001$ \\
\hline $\mathrm{PAB}^{\S}$ & $44.59 \pm 15.57$ & $36.40 \pm 12.00$ & $<0.001$ \\
\hline Uric acid (mg/dl) & $5.98 \pm 0.58$ & $5.83 \pm 2.00$ & 0.770 \\
\hline LDH/albumin ratio & $102.53 \pm 55.18$ & $74.31 \pm 34.71$ & $<0.001$ \\
\hline
\end{tabular}

${ }^{*}$ Mean corpuscular volume

${ }^{+}$Mean platelet volume

${ }^{\ddagger}$ Red cell diameter width

$\S$ Pulmonary artery pressure 
Figure 1. Receiver operating characteristics curve analysis for test parameters.

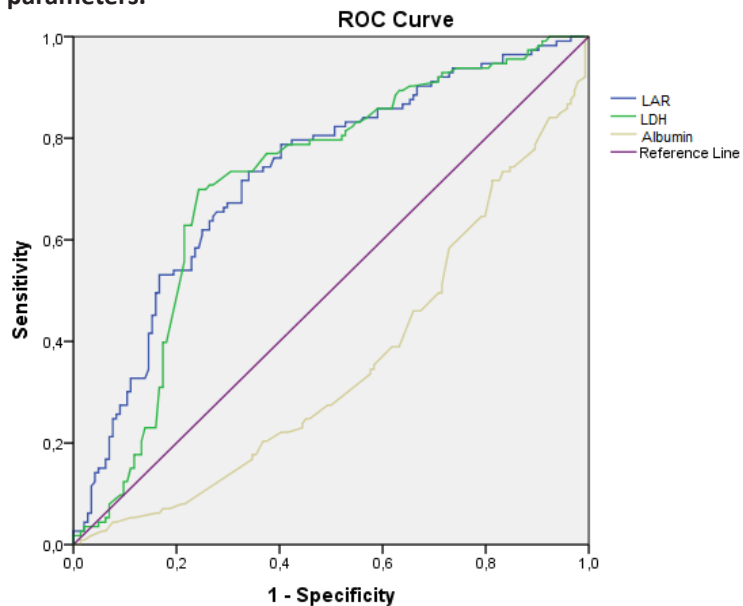

LAR: Lactate dehydrogenase to albumin ratio, LDH: lactate dehydrogenase

Table 3: Sensitivity, specificity, positive and negative predictive values for lactate dehydrogenase to albumin ratio in the diagnosis of pulmonary thromboembolism.

\begin{tabular}{|l|c|c|}
\hline & Value & $95 \%$ Confidence interval \\
\hline Sensitivity & $71.7 \%$ & $62.4-79.7 \%$ \\
\hline Specificity & $67.4 \%$ & $59.1-74.9 \%$ \\
\hline Positive predictive value & $63.3 \%$ & $57.0-69.1 \%$ \\
\hline Negative predictive valur & $75.2 \%$ & $68.9-80.6 \%$ \\
\hline Disease prevalance & $43.4 \%$ & $37.8-50.3 \%$ \\
\hline
\end{tabular}

\section{DISCUSSION}

According to the results of this study, LAR is significantly higher in patients with PTE compared to those without. In ROC analysis, relation of LAR to PTE was found to be stronger than $\mathrm{LDH}$ and albumin tests alone. Also, in the PTE group, neutrophil and monocyte counts and D-dimer levels were significantly higher and albumin level was significantly lower compared to the control group.

In a study reported from Sweden, 347 patients hospitalized in intensive care unit were investigated and LAR was found to be significantly associated with multiorgan failure and 30-day mortality ${ }^{(10)}$. A study from China with 139 pancreas cancer patients who did not undergo surgical intervention reported that patients having higher LAR had shorter survival times. The reason for increased LAR was explained with higher LDH levels due to tissue injury related to tumor and higher metabolic turnover in tumoral tissue, and lower albumin levels, since albumin has an antioxidant and protective properties ${ }^{(8)}$.
Inflammation, hypercoagulation and endothelial injury are main reasons for thromboembolism ${ }^{(11)}$. Thromboembolism directly caused by inflammation was also reported before ${ }^{(12)}$. LDH can be found in every type of cells and will naturally increase in any ischemic and oxidative condition causing cell injury (6). LDH was reported to be associated with mortality in PTE ${ }^{(13)}$. Hypoalbuminemia was associated with inflammation ${ }^{(14)}$. In a study from USA with 15300 people, authors reported increased rates of thromboembolism in cases with hypoalbuminemia (5). Similarly, in a study on 552 patients with PTE hypoalbuminemia was found to be associated with severity of PTE ${ }^{(15)}$. There are several reasons for this association. Albumin suppresses fibrin polymerization and platelet aggregation (16). Albumin promotes effects of antithrombin III with its heparin-like effect (17). In a study with 7266 patients, it was reported that hypoalbuminemia aggravated inflammation and inflammation aggravated thromboembolism (18). Increase in LDH and decrease in albumin levels were separately associated with PTE, but this present study evaluates combined effects of both by LAR for the first time.

A study reported increased leukocyte counts ${ }^{(19)}$ and another study reported higher monocyte and leukocyte counts in patients who died within one month after onset of PTE, compared to survived patients ${ }^{(20)}$. Similarly, in this study; neutrophil and monocyte counts were significantly higher in patients with PTE compared to the control group.

It is known that D-dimer levels are increased in patients with PTE and low D-dimer levels rule out diagnosis of PTE ${ }^{(21)}$. The results of this study shows that D-dimer levels were higher in patients with PTE compared to those without.

Pulmonary artery pressure is a reliable indicator of right ventricular dysfunction developed in PTE which is associated with severity of PTE ${ }^{(22)}$. This study also reports higher PAP values in patients with PTE.

This study has some limitations. Before all, it is a retrospective study that relied on recorded data, thus only data from patients, in whom all study parameters could be obtained completely, were used. Since mortality rate of PTE was low in 
hospitalization period, prognostic evaluation could not be made in these patients.

In conclusion; according to the results of this study, LAR may be used as a novel diagnostic parameter in PTE. LAR, calculated from very simple and available parameters such as LDH and albumin, may be helpful in the diagnosis of PTE. Further studies with greater number of participants are required for evaluation of LAR. Association of LAR with severity of PTE should be investigated in prospective studies with randomized controlled trial setup.

Ethics Committee Approval: Lokman Hekim University Non-Interventional Clinical Research Ethics Committee (2020/016, 07.03.2020).

Conflict of Interest: No conflict of interest was declared by authors.

Funding: This study was not financially supported. Informed Consent: Written informed consents were obtained from all participants.

\section{REFERENCES}

1. Rali P, Gandhi V, Malik K. Pulmonary embolism. Crit Care Nurs Q. 2016;39(2):131-8. doi: $10.1097 / C N Q .0000000000000106$.

2. Tapson VF. Acute pulmonary embolism. N Engl J Med. 2008;358(10):1037-52. doi: 10.1056/NEJMra072753

3. Eagleton MJ, Henke PK, Luke CE, Hawley AE, Bedi A, Knipp BS, et al. Southern Association for Vascular Surgery William J. von Leibig Award. Inflammation and intimal hyperplasia associated with experimental pulmonary embolism. J Vasc Surg. 2002;36(3):581-8 doi: $10.1067 /$ mva.2002.126556.

4. Mahmoodi BK, Gansevoort RT, Veeger NJ, Matthews AG, Navis G, Hillege HL, van der Meer J. Microalbuminuria and risk of venous thromboembolism. JAMA. 2009;301:1790-7. doi: 10.1001/jama.2009.565.

5. Folsom AR, Lutsey PL, Heckbert SR, Cushman M. Serum albumin and risk of venous thromboembolism. Thromb Haemost. 2010;104(1):100-4 doi: 10.1160/TH09-12-0856.

6. Lemasters JJ, Stemkowski CJ, Ji S, Thurman RG. Cell surface changes and enzyme release during hypoxia and reoxygenation in the isolated, perfused rat liver. J Cell Biol. 1983;97(3):778-86. doi: 10.1083/jcb.97.3.778.

7. Feng JF, Wang L, Yang $X$, Jiang $Y$ H. Prognostic value of lactate dehydrogenase to albumin ratio (LAR) in patients with resectable esophageal squamous cell carcinoma. Cancer Manag Res. 2019;11:7243-51. doi: 10.2147/CMAR.S208320.

8. Gao S, Wu M, Chen Y, Lou W, Zhou G, Li J, et al. Lactic dehydrogenase to albumin ratio in prediction of unresectable pancreatic cancer with intervention chemotherapy. Future
Oncol. 2018;14(14):1377-86.

doi: 10.2217/fon-2017-0556.

9. Gan $W$, Zhang $M X$, Wang JX, Fu YP, Huang JL, Yi $Y$, et al. Prognostic impact of lactic dehydrogenase to albumin ratio in hepatocellular carcinoma patients with Child-Pugh I who underwent curative resection: a prognostic nomogram study. Cancer Manag Res. 2018;10:5383-94. doi: 10.2147/CMAR. S176317.

10. Helliksson F, Wernerman J, Wiklund L, Rosell J, Karlsson M. The combined use of three widely available biochemical markers as predictor of organ failure in critically ill patients. Scand J Clin Lab Invest. 2016;76(6):479-85. doi: 10.1080/00365513.2016.1201850.

11. Piazza G, Goldhaber SZ. Venous thromboembolism and atherothrombosis: an integrated approach. Circulation. 2010;121(19):2146-50. doi: 10.1161/CIRCULATIONAHA.110.951236.

12. Saghazadeh A, Rezaei N. Inflammation as a cause of venous thromboembolism. Crit Rev Oncol Hematol. 2016;99:272-85. doi: 10.1016/j.critrevonc.2016.01.007.

13. Leite L, Moura J, Ferreira R, Lazaro S, Madaleno J, Moreira N, et al. LDH as a predictor of in-hospital and late mortality in acute pulmonary embolism. Eur Heart J. 2013;34(suppl. 1):P1154. doi: 10.1093/eurheartj/eht308.P1154.

14. Das S, Maras JS, Hussain MS, Sharma S, David P, Sukriti S, et al. Hyperoxidized albumin modulates neutrophils to induce oxidative stress and inflammation in severe alcoholic hepatitis. Hepatology. 2017;65(2):631-46. doi: 10.1002/hep.28897.

15. Omar HR, Mirsaeidi M, Rashad R, Hassaballa H, Enten G, Helal $\mathrm{E}$, et al. Association of Serum Albumin and Severity of Pulmonary Embolism. Medicina (Kaunas). 2020;56(1):26. doi: 10.3390/medicina56010026.

16. Mikhailidis DP, GanotakiES. Plasma albumin and platelet function: relevance to atherogenesis and thrombosis. Platelets. 1996;7(3):125-37. doi: 10.3109/09537109609023571.

17. Jøorgensen KA, Stoffersen E. Heparin like activity of albumin. Thromb Res. 1979;16(3-4):569-74. doi: 10.1016/0049-3848(79)90105-1.

18. Chi G, Gibson CM, Liu Y, Hernandez AF, Hull RD, Cohen AT, et al. Inverse relationship of serum albumin to the risk of venous thromboembolism among acutely ill hospitalized patients: Analysis from the APEX trial. Am J Hematol. 2019;94(1):21-8. doi: 10.1002/ajh.25296.

19. Sasahara AA, Cannilla JE, Morse RL, Sidd JJ, Tremblay GM. Clinical and physiologic studies in pulmonary thromboembolism. Am J Cardiol. 1967;20(1):10-20. doi: 10.1016/0002-9149(67)90105-1.

20. Efe TH, Arslan ED, Ertem AG, Yayla C, Felekoğlu MA, İnci S, et al. The prognostic value of the monocyte/hdl ratio in predicting short-term mortality in patients with acute pulmonary embolism. Kosuyolu Heart J. 2016;19(3):149-153. Available from: https://kosuyoluheartjournal.com/full-textpdf/1234/tur

21. Perrier A, Desmarais S, Goehring C, Moerloose P, Morabia A, Unger PF, et al. D-dimer testing for suspected pulmonary embolism in outpatients. Am J Respir Crit Care Med. 1997;156(2 Pt 1):492-6. doi: 10.1164/ajrccm.156.2.9702032.

22. Keller K, Geyer M, Coldewey M, Beulec J, Balzer JO, Dippold W. Elevated systolic pulmonary artery pressure for prediction of myocardial necrosis and right ventricular dysfunction in acute pulmonary embolism. Cor et Vasa. 2016;58(4):e403-10. doi: 10.1016/j.crvasa.2015.12.001. 